\title{
The Influence of Dissolved Oxygen on the Electrochemical Behavior of Mild Steel in Neutral Solution at Temperatures up to $280^{\circ} \mathrm{C}$
}

\author{
By Tetsuo Fujii* and Toyoji Kobayashi*
}

\begin{abstract}
In order to study the electrochemical behavior of mild steel in high temperature aqueous solution, potentiodynamic polarization curves were measured in $0.1 \mathrm{~N}$ sodium sulfate solution up to $280^{\circ} \mathrm{C}$ by using an external reference electrode system.

Passivation phenomena were observed at temperatures above $200^{\circ} \mathrm{C}$ in deareated solution, and above $250^{\circ} \mathrm{C}$ in airsaturated solution. However, the corrosion of specimen was always greater in air-saturated solution than that in deaerated solution. Pitting behavior also appeared under the deaerated condition at 200 and $250^{\circ} \mathrm{C}$.

From the results of $\mathrm{X}$-ray and electron diffraction, the passivity under the deaerated condition will be attributed to the protective oxide of magnetite. On the other hand, the presence of hematite in oxide seems to be related to the apparent passivity under the air-saturated condition.
\end{abstract}

\author{
(Received June 21, 1972)
}

\section{Introduction}

Dissolved oxygen in boiler feed water is extremely expelled to reduce the corrosion of carbon steel in high temperature water, since oxygen can act as a cathodic depolarizer. However, the role of oxygen as a passivator has also been reported by several workers. Nesmeyanova(1) has shown that the corrosion of carbon steel and a stainless steel in deaerated water at $300^{\circ} \mathrm{C}$, is reduced by the addition of oxygen. Wilde ${ }^{(2)}$ has reported that oxygen over the range of 0.08 to 50 ppm increased the corrosion rate of carbon steel, while at $100 \mathrm{ppm} \mathrm{O}_{2}$ the corrosion rate decreased to $0.2 \mathrm{mdd}$ at $289^{\circ} \mathrm{C}$. Butler et al. ${ }^{(3)}$ and Gerasimov et al. ${ }^{(4)}$ have obtained similar results, in which they observed the ennoblement effect of potentials on iron by the introduction of oxygen into deaerated solution at high temperature. We have also found in the previous work $^{(5)}$ that oxygen shifts the corrosion potential of stainless steel toward a noble direction and passive current was smaller in air-saturated solution than in the deaerated one at high temperature and pressure.

For in situ electrochemical measurement at high temperature and pressure, two techniques have been developed. One is an internal reference electrode system, in which a reference electrode, such as an $\mathrm{Ag}-\mathrm{AgCl}$ electrode is maintained at the same temperature and pressure as a test electrode in an autoclave. This method is based on the principle of electrochemistry, since the standard hydrogen electro le potential is defined as zero at all temperatures. However, reference electrodes which show a stable and reliable potential are very few at high temperature. It has also been reported ${ }^{(6)}$ that the internal electrode often act as an oxygen electrode in the presence of

* National Research Institute for Metals, Meguro-ku, Tokyo, Japan.

(1) K. N. Nesmeyanova: 3rd Int. Conf. Metallic Corrosion, Moscow, (1966).

(2) B. E. Wilde: Corrosion, 24 (1968), 358.

(3) G. Butler, P. E. Francis, and A. S. Mackie: Corr. Sci., 9 (1969), 715.

Trans. JMM oxygen, so that the potential difference between the reference and test electrodes is generally very small. The second technique is an external reference electrode system, in which the reference electrode is placed outside an autoclave and has electrolytic contact with test solution through a capillary tube. In this method, although undesirable effects such as thermal junction and streaming potentials are accompanied, contamination of the test solution from the reference electrode solution, e.g. chloride ion from $\mathrm{Ag}-\mathrm{AgCl}$ electrode, can be avoided and the presence of oxygen does not affect the measured potential.

In this work, potentiodynamic polarization behavior of mild steel was examined in $0.1 \mathrm{~N}$ sodium sulfate over the temperatures $100^{\circ} \mathrm{C}$ to $280^{\circ} \mathrm{C}$ by using the external reference electrode system. Subsequently, the effects of oxygen and temperature on the high temperature passivation phenomena of steel will be discussed together with structural features of the oxide film formed on specimens.

\section{Experimental}

The experimental apparatus for the electrochemical measurement in an autoclave has already been described elsewhere ${ }^{(5)}$. In the present external reference electrode system, the streaming potential was previously confirmed to be sufficiently small by the inspection of the cellulose plug pressurized with argon gas at room temperature. Although the thermal junction potential across the solution bridge was not taken into account in this work, its contribution to the measured potential will be insignificant for the discussion of the passivation phenomena.

A $500 \mathrm{~mL}$ autoclave made of 304 stainless steel, served as an electrolytic cell. No liner was used in the autoclave, since the autoclave wall was well oxidized

(4) V. V. Gerasimov, et al.: Corrosion of Reactor Materials, AEC Report, (1962).

(5) T. Fujii, T. Kobayashi, and G. Ito: J. Japan Inst. Metals, 35 (1971), 47.

(6) M. E. Indig, and D. A. Vermilyea: Corrosion, 27 (1971), 312.

1973 Vol. 14 
before use. Specimens, $10 \mathrm{~mm}$ in diameter and $30 \mathrm{~mm}$ in length, were cut from a mild steel rod of the following chemical composition; C, 0.17; Si, 0.01; Mn, $0.38 ; \mathrm{P}, 0.011 ; \mathrm{S}, 0.012$ per cent. After having been annealed at $900^{\circ} \mathrm{C}$ for $30 \mathrm{~min}$, specimens were successively polished with polishing paper to No 600 and degreased in acetone. One end of the specimen was tightly screwed to the rod of the electrode conductor covered with an alumina tube through teflon gasket. The exposed area of the specimen was 9.4 sq. $\mathrm{cm}$.

A $25 \times 30 \mathrm{~mm}$ platinum plate served as a counter electrode. A saturated calomel electrode as an external reference electrode was placed outside the autoclave at room temperature. All potentials shown in this article are expressed in terms of volt referred to the saturated calomel electrode at room temperature. The test solution, $0.1 \mathrm{~N}$ sodium sulfate ( $\mathrm{pH} 6.5$ ), was prepared from deionized water and analytical grade sodium sulfate.

The deaerated condition was attained by bubbling pure argon gas through the test solution for at least 3 $\mathrm{hr}$, and then heated to the desired temperature. By this process, the oxygen level in the test solution was reduced to below $0.1 \mathrm{ppm}$. Experiments under the airsaturated condition were carried out in the solution previously saturated with air at room temperature ( $\sim 8 \mathrm{ppm}_{2}$ at room temperature).

An electrometer (Takeda Riken, TR-8651) was used for the measurement of corrosion potential during heating of the autoclave. Potentiodynamic polarization curves were taken with a potentiostat (Shimadzu PS-2) at a rate of $50 \mathrm{mV}$ per min.

Corrosion products formed on the specimen were examined by X-ray and electron diffraction after exposure.

\section{Results}

Typical potential-time curves during heating are represented in Fig. 1. Under the deaerated condition, the corrosion potential at room temperature lowered to $-0.80 \mathrm{~V}$ (S.C.E.) by bubbling argon gas. With increase in temperature, the corrosion potential changed slightly in the noble direction and settled

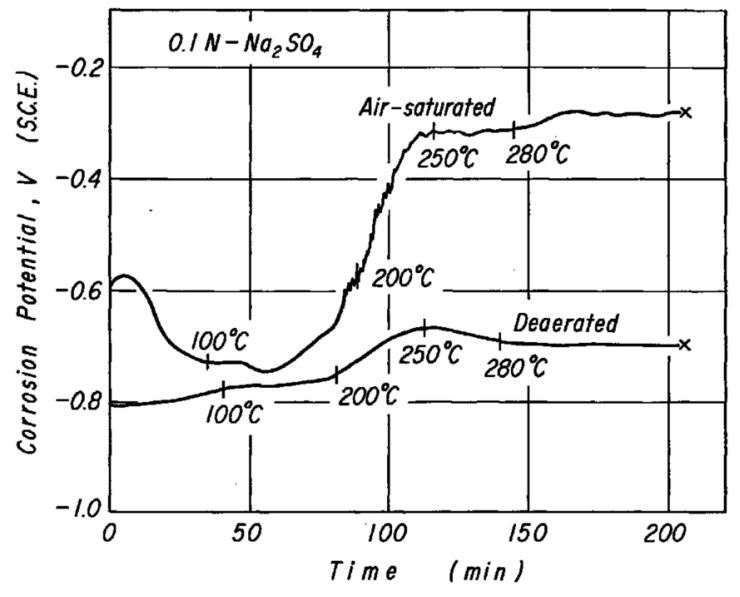

Fig. 1 Representative potential-time curves during heat up for mild steel in $0.1 \mathrm{~N}-\mathrm{Na}_{2} \mathrm{SO}_{4}$ at high temperature. down at about $-0.72 \mathrm{~V}$ at $280^{\circ} \mathrm{C}$. Under the airsaturated condition, initially the corrosion potential changed in the less noble direction up to $150^{\circ} \mathrm{C}$. This potential change will predict the active dissolution process of the specimen. Above $180^{\circ} \mathrm{C}$ the corrosion potential shifted in the opposite direction, accompanied with oscillation of the potential, and settled down appreciably at a higher potential above $200^{\circ} \mathrm{C}$. Mild steel tends to be selfpassivated at a temperature above $200^{\circ} \mathrm{C}$. These potential-time curves were very reproducible, when the heating rate of the autoclave was kept constant.

Potentiodynamic polarization curves were taken by the potential scan in the noble direction from the cathodic potential region, after holding for one hour

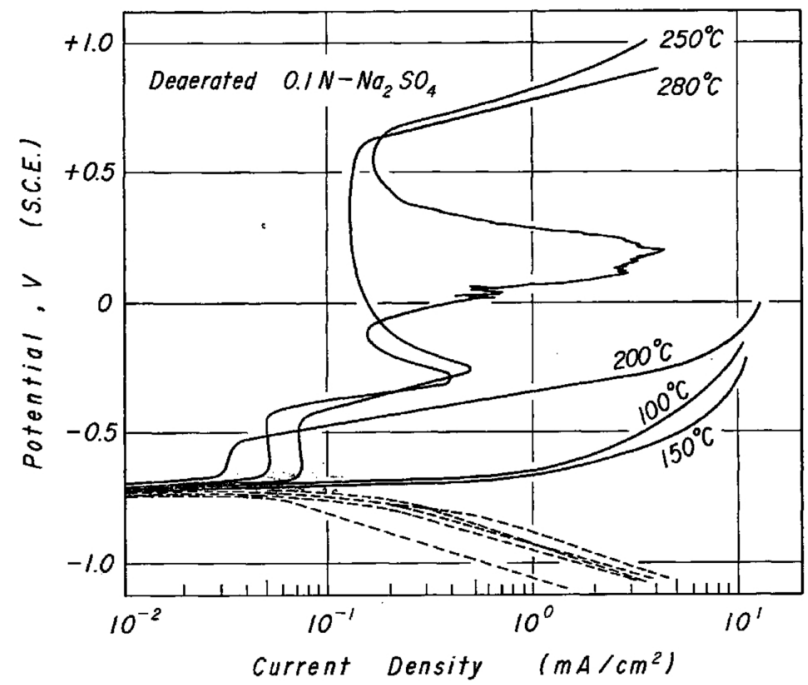

Fig. 2 Potentiodynamic polarization curves for mild steel in deaerated $0.1 \mathrm{~N}-\mathrm{Na}_{2} \mathrm{SO}_{4}$.
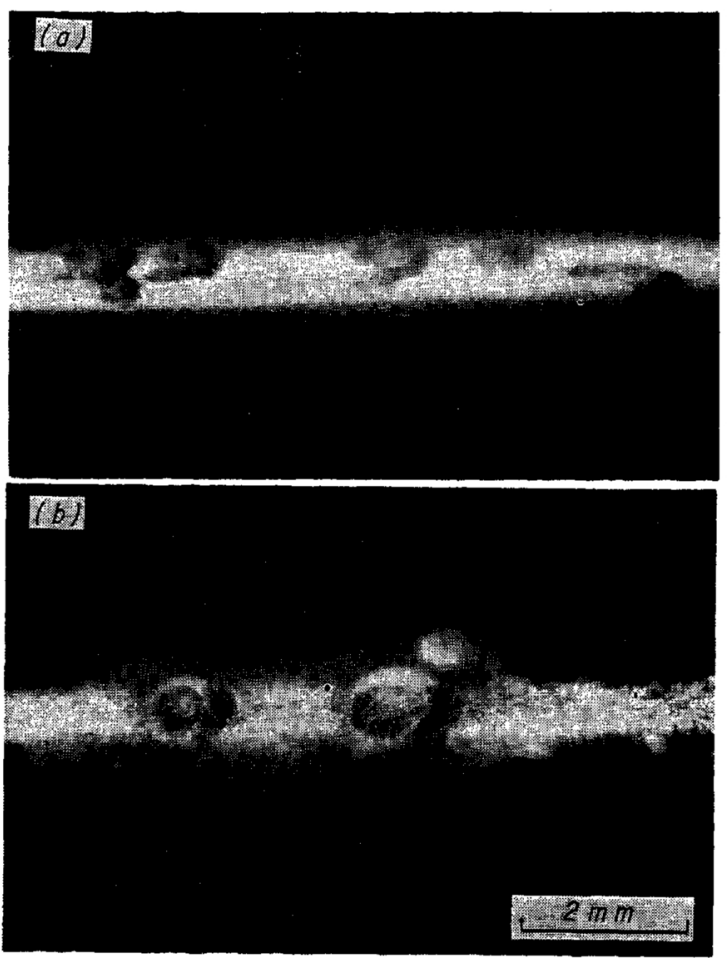

Photo. 1 Corroded surfaces anodically polarized in deaerated $0.1 \mathrm{~N}-\mathrm{Na}_{2} \mathrm{SO}_{4}$ solution at (a) $200^{\circ} \mathrm{C}$ and (b) $250^{\circ} \mathrm{C}$. 


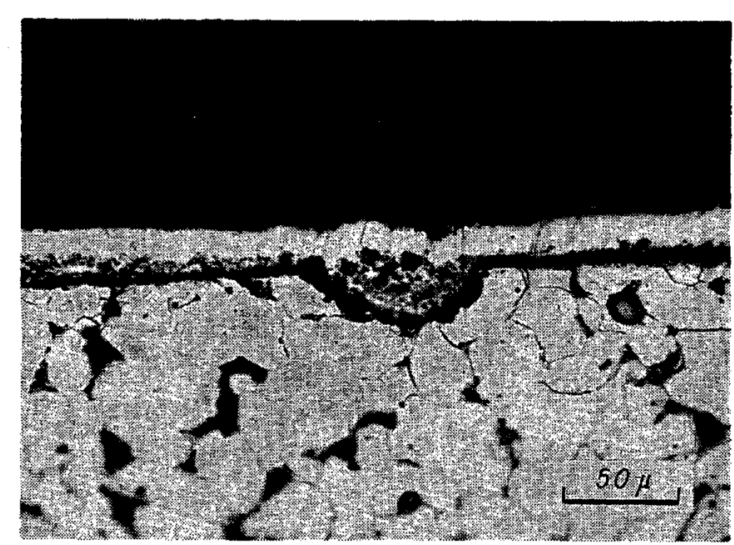

Photo. 2 Cross section of a pit perpendicular to specimen surface.

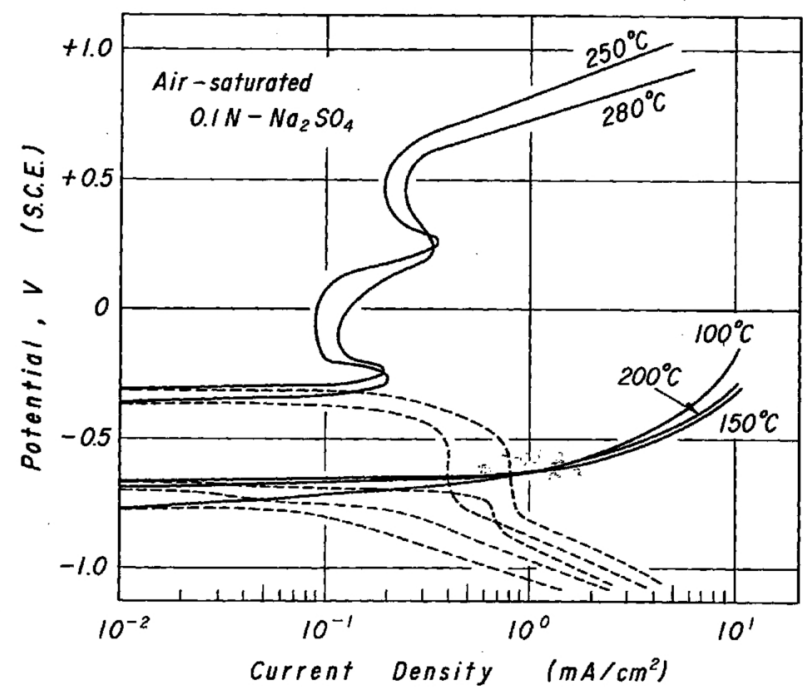

Fig. 3 Potentiodynamic polarization curves for mild steel in air-saturated $0.1 \mathrm{~N}-\mathrm{Na}_{2} \mathrm{SO}_{4}$.

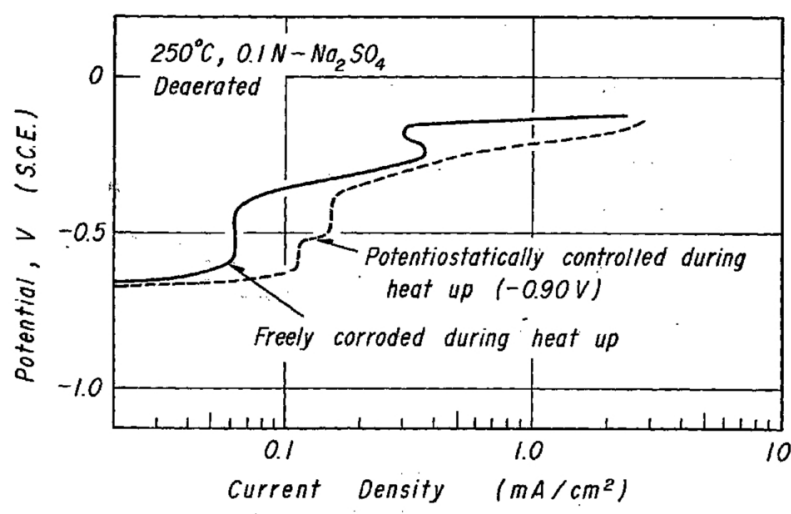

Fig. 4 Effect of cathodic polarization $(-0.90 \mathrm{~V}$, S.C.E.) during heating up for the potentiodynamic polarization behavior of mild steel at $250^{\circ} \mathrm{C}$.

at each test temperature. Polarization curves under the deaerated condition are shown in Fig. 2. Cathodic polarization curves, which are shown by dotted lines, moved in the direction of higher current density, as the temperature is increased. In the anodic curves, no active-passive transition was observed below $150^{\circ} \mathrm{C}$. However, at $200^{\circ} \mathrm{C}$ there is a passive region followed by a marked increase in current. The appearance of the

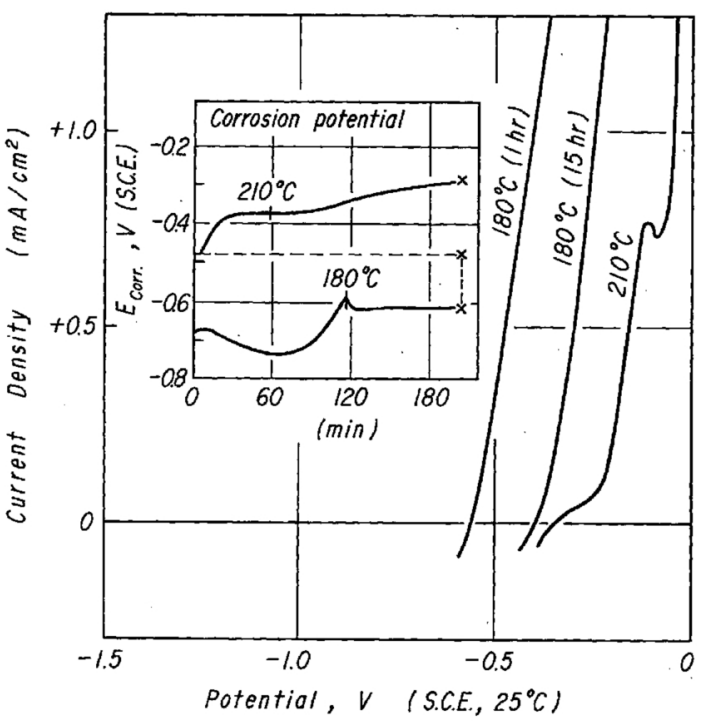

Fig. 5 Effect of temperature on passivation phenomena of mild steel in air-saturated $0.1 \mathrm{~N}-$ $\mathrm{Na}_{2} \mathrm{SO}_{4}$.

specimen surface which underwent anodic polarization, is shown in Photo. 1. A typical pit cross section is shown in Photo. 2. At $250^{\circ} \mathrm{C}$, two distinct current maxima appeared at -0.3 and $+0.25 \mathrm{~V}$ in the anodic curve. In some other experiments at the same temperature, however, a pitting behavior similar to that of $200^{\circ} \mathrm{C}$ was often observed. These behaviors are very similar to the I-E curve obtained during the pitting process at ambient temperature. Although at $280^{\circ} \mathrm{C}$ pitting was no longer observed, a number of small pores were observed on the surface of oxide films with a microscope. In the case of air-saturated solution, no passivation appeared up to $200^{\circ} \mathrm{C}$, as shown in Fig. 3 . When the temperature was raised to 250 and $280^{\circ} \mathrm{C}$, the corrosion potentials shifted above $-0.35 \mathrm{~V}$ and two current maxima appeared at about -0.25 and $+0.20 \mathrm{~V}$. These current peaks were approximately in agreement with those of deaerated solution. In the cathodic curves a limiting diffusion current of oxygen reduction increased markedly at 250 and $280^{\circ} \mathrm{C}$.

From the corrosion potential and polarization curves, the self-passivation of mild steel seems to begin at temperatures higher than $200^{\circ} \mathrm{C}$. An anodic polarization curve on the specimen potentiostatically kept at $-0.90 \mathrm{~V}$ (S.C.E.) during heating showed no marked difference from the result on the freely corroded specimen during heating (Fig. 4). Passivation potential under the deaerated condition, therefore, should be in a less noble potential below $-0.90 \mathrm{~V}$.

On the other hand, in order to clarify the passivation temperature in the air-saturated solution, polarization temperature in the air-saturated solution, polarizaresults are shown in Fig. 5. The corrosion potential followed the same potential time curve as shown in Fig. 1. When the temperature reached $180^{\circ} \mathrm{C}$, an anodic curve was measured, but there was no indication of passivation. After the specimen was held at the same temperature for $15 \mathrm{hr}$, the corrosion potential moved at $-0.45 \mathrm{~V}$, but no passivation was observed 


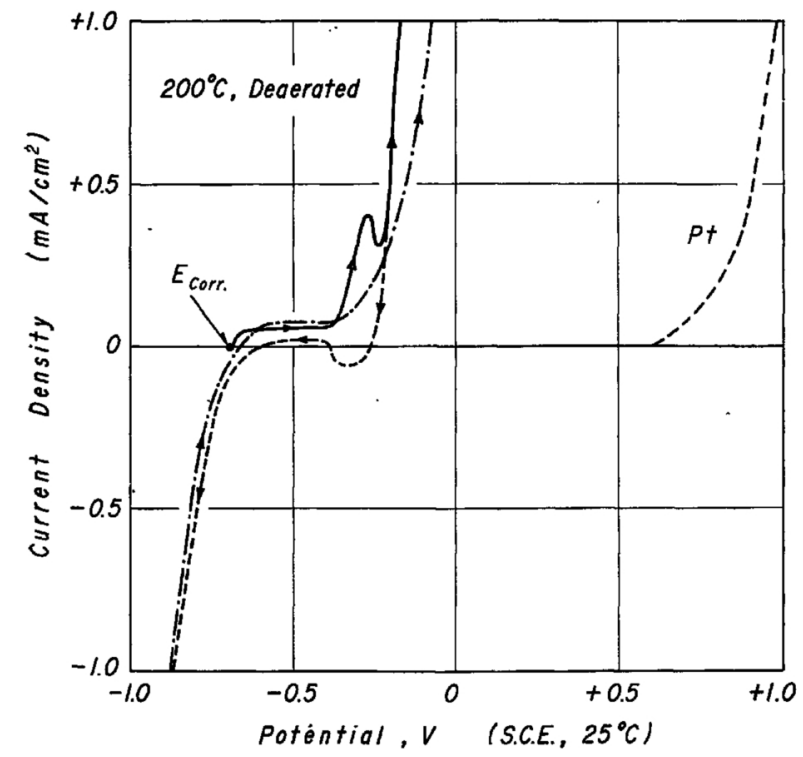

Fig. 6 Effect of potential increase and decrease for the passivity of mild steel in deaerated $0.1 \mathrm{~N}-$ $\mathrm{Na}_{2} \mathrm{SO}_{4}$ at $200^{\circ} \mathrm{C}$.

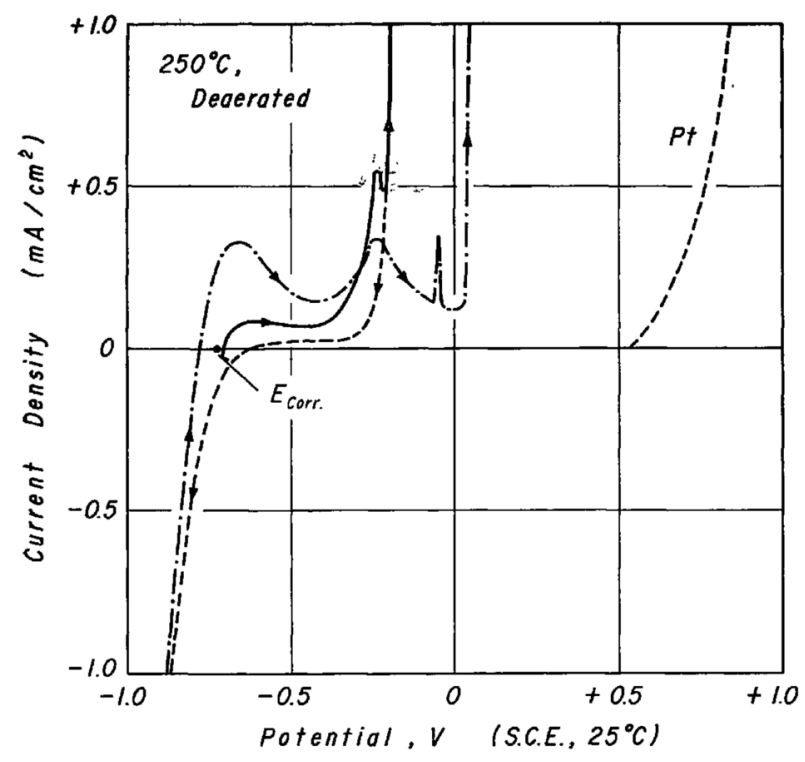

Fig. 7 Effect of potential increase and decrease for the passivity of mild steel in deaerated $0.1 \mathrm{~N}-$ $\mathrm{Na}_{2} \mathrm{SO}_{4}$ at $250^{\circ} \mathrm{C}$

in the anodic polarization curve. The temperature of the autoclave was then raised to $210^{\circ} \mathrm{C}$. The corrosion potential gradually changed in the noble direction and the determined polarization curve revealed an indication of passivation. It seems to take longer time for the passivity to be attained below $200^{\circ} \mathrm{C}$.

In order to clarify the stability of high-temperature passivity formed on the mild steel, the effects of potential increase and decrease on the anodic polarization curves were studied. Figures 6 to 11 represent the effect of positive and reverse scans on the potentiodynamic polarization behavior. Every scan was started from the corrosion potential. In the deaerated solution at 200 and $250^{\circ} \mathrm{C}$ the direction of potential scan was reversed at $-0.15 \mathrm{~V}$ and $-0.10 \mathrm{~V}$, respectively, since a large amount of current by pitting might

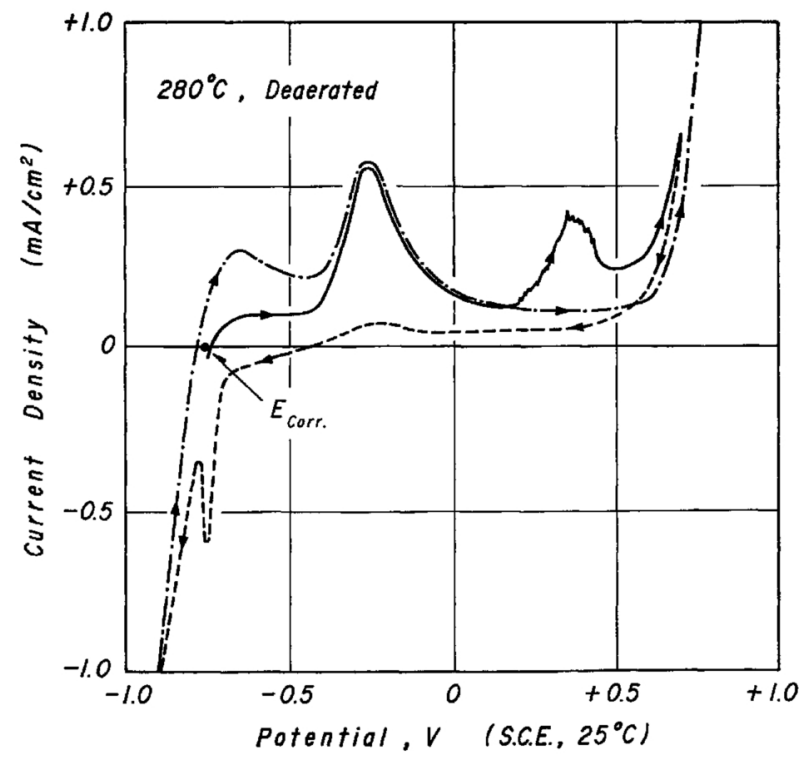

Fig. 8 Effect of potential increase and decrease for the passivity of mild steel in deaerated $0.1 \mathrm{~N}-$ $\mathrm{Na}_{2} \mathrm{SO}_{4}$ at $280^{\circ} \mathrm{C}$.

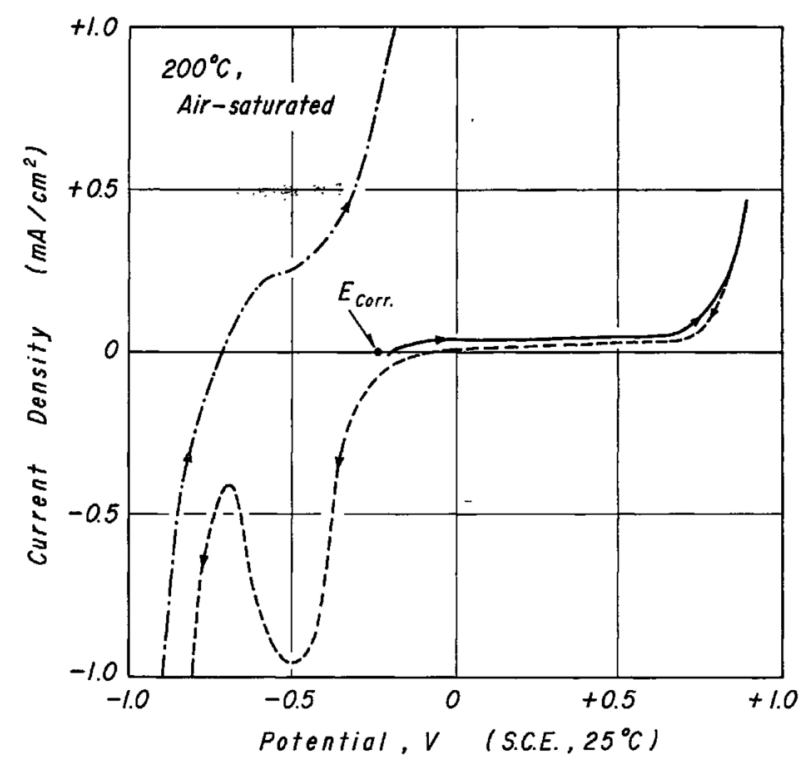

Fig. 9 Effect of potential increase and decrease for the passivity of mild steel in air-saturated $0.1 \mathrm{~N}$ $\mathrm{Na}_{2} \mathrm{SO}_{4}$ at $200^{\circ} \mathrm{C}$.

disturb the surface condition of specimens. In the reverse scan, the noble to the active direction, a small cathodic loop was observed at about $-0.35 \mathrm{~V}$. This will correspond to a blip in the first positive scan. Anodic polarization curves corresponding to the oxygen evolution reaction on $\mathrm{Pt}$ are also shown in Figs. 6 and 7. A full anodic polarization curve was obtained at $280^{\circ} \mathrm{C}$. Although in the first positive scan the second peak appeared at $+0.40 \mathrm{~V}$, it did not appear in the reverse and second positive scans.

In the air-saturated solution at $200^{\circ} \mathrm{C}$, the positive scan, active to noble, from the corrosion potential exhibited no current peak up to oxygen evolution, but in the reverse scan a temporary decrease of cathodic current was found at $-0.70 \mathrm{~V}$. In the positive scan, passivity was no longer observed. This behavior might 


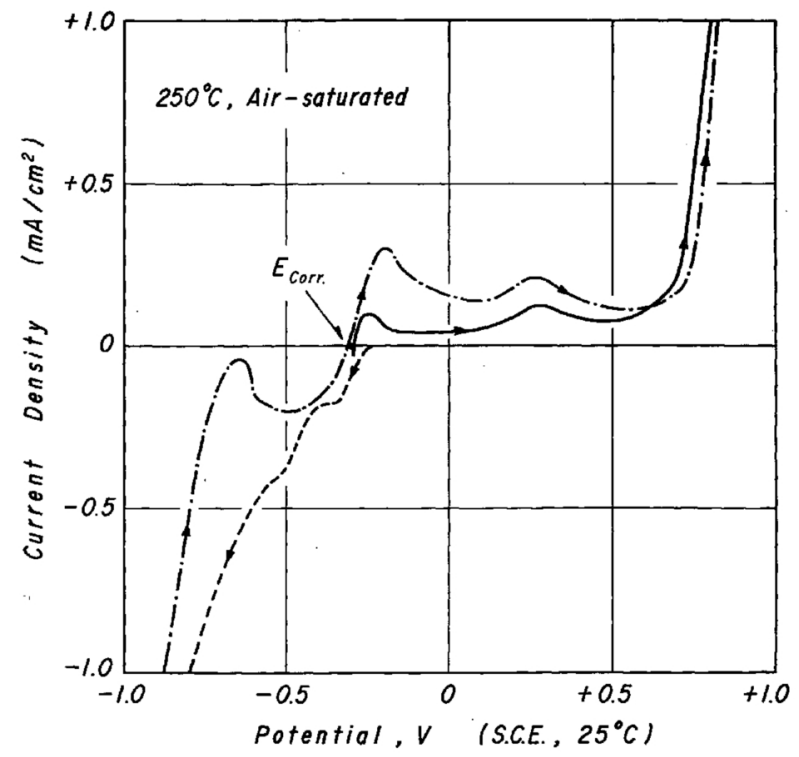

Fig. 10 Effect of potential increase and decrease for the passivity of mild steel in air-saturated $0.1 \mathrm{~N}-\mathrm{Na}_{2} \mathrm{SO}_{4}$ at $250^{\circ} \mathrm{C}$.

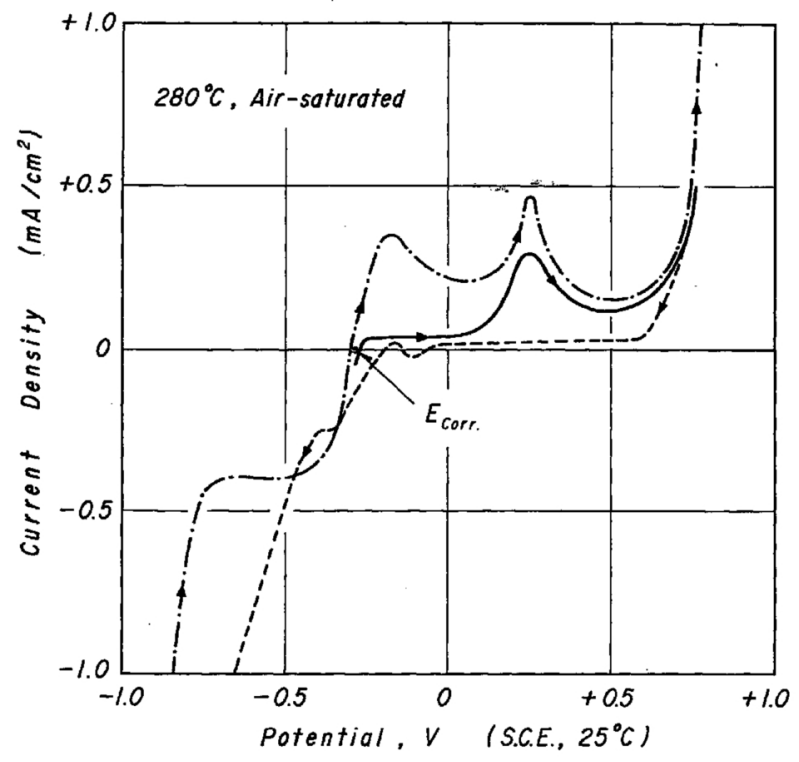

Fig. 11 Effect of potential increase and decrease for the passivity of mild steel in air-saturated $0.1 \mathrm{~N}-$ $\mathrm{Na}_{2} \mathrm{SO}_{4}$ at $280^{\circ} \mathrm{C}$.

be caused by the reduction of the passive film during the foregoing cathodic polarization. At $250^{\circ} \mathrm{C}$, the anodic partial reaction at $-0.70 \mathrm{~V}$ was markedly depressed in the reverse scan, and the specimen was readily passivated in the second scan of positive direction. Two current maxima were found at -0.25 and $+0.25 \mathrm{~V}$. The first current maximum seems to correspond to the blip potential in the positive scan under the deaerated condition, but the reduction current of the second peak was not observed. A similar tendency was also found at $280^{\circ} \mathrm{C}$.

The current increase at a higher potential seems to be due to the oxygen evolution reaction. The I-E curves taken on Pt in the same media and temperature approximately agreed with that of mild steel at a higher potential. In constant potential experiments, a

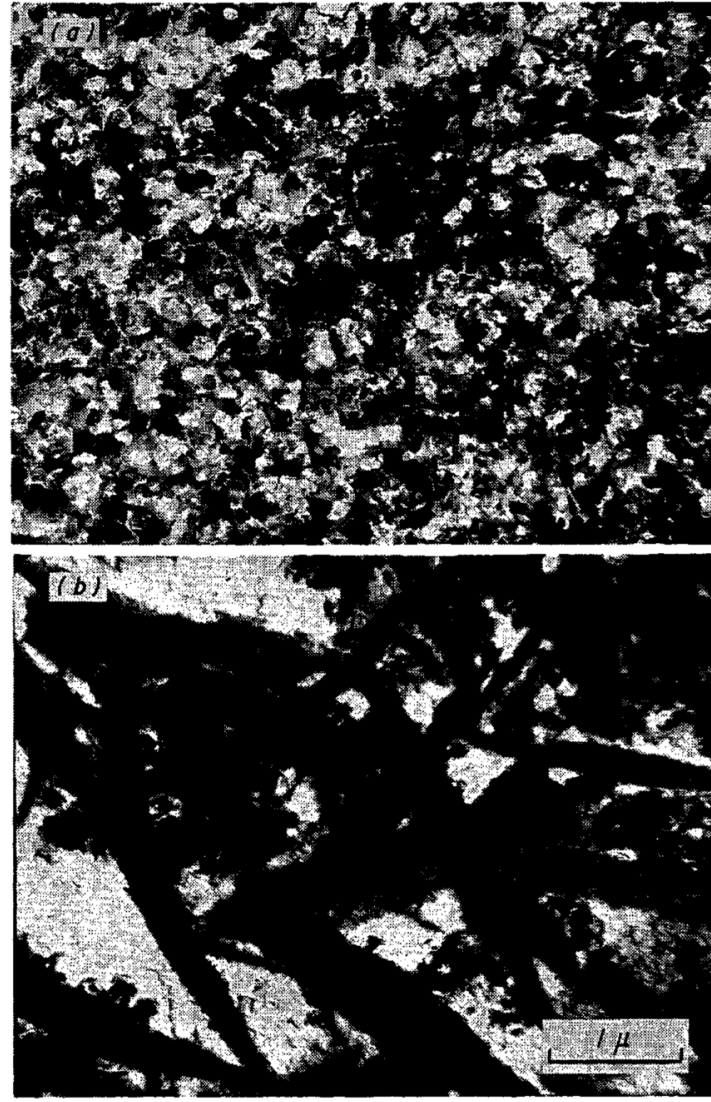

Photo. 3 Electron micrographs showing the structure of oxide films formed in (a) deaerated and (b) air-saturated $0.1 \mathrm{~N}-\mathrm{Na}_{2} \mathrm{SO}_{4}$ solution at $280^{\circ} \mathrm{C}$.

steady decay in current with time was generally observed in the passive potential range, but above $+0.70 \mathrm{~V}$ an appreciably higher constant current with time was observed.

Surface oxide films produced on the unpolarized and polarized specimens were first examined by X-ray diffraction, and then identified by transmission electron analysis on the chemically stripped oxide film by brom methanol methanol solution. With the deaerated solution a principal component of thin protective oxide was always magnetite which had an adherent and wellcrystallized structure. Weak diffraction from $\gamma$ $\mathrm{Fe}_{2} \mathrm{O}_{3}$ was obtained in the corrosion products formed at $250^{\circ} \mathrm{C}$ in deaerated solution and 200,250 and $280^{\circ} \mathrm{C}$ in the air-saturated solution. However, $\alpha-\mathrm{Fe}_{2} \mathrm{O}_{3}$ was detected only under the air-saturated condition. Photograph 3 shows typical electron microphotographs of oxide film on freely corroded specimen in high temperature solution. Leaf-like structure can be seen in the micrograph obtained under the air-saturated condition. Selected electron diffractions from the matrix and the leaf-like structure showed a welldefined magnetite and a spotty pattern of $\alpha-\mathrm{Fe}_{2} \mathrm{O}_{3}$, respectively. The surface of the oxide film was also examined with an optical microscope under crossed nicols. In general, the oxide film formed on the freely corroded specimen in air-saturated solution revealed locally the presence of an optically anisotropic oxide of $\alpha-\mathrm{Fe}_{2} \mathrm{O}_{3}$. On the specimens electrochemically polarized in the deaerated solution, bright images were 
observed preferentially within pits under crossed nicols.

\section{Discussion}

In the weight loss measurement performed in previous work $^{(7)}$, it was shown that the corrosion rate of mild steel was always greater in air-saturated solution than that in deaerated solution, and under the air-saturated condition the corrosion rate markedly decreased above $250^{\circ} \mathrm{C}$.

These phenomena can be explained by the present experimental results. In deaerated solution, corrosion potentials were settled down at a somewhat less noble potential, but specimens were covered with a protective thin oxide consisting of magnetite. The subsequent anodic polarization curve gave passive current densities of about 50 to $100 \mu \mathrm{A} / \mathrm{cm}^{2}$. Accordingly, the passivation potential of mild steel will be at a highly negative potential, probably below $-0.90 \mathrm{~V}$ (Fig. 4).

On the other hand, the corrosion potential under the air-saturated condition was very close to the first current peak $\left(-0.25 \mathrm{~V}\right.$, at $\left.280^{\circ} \mathrm{C}\right)$ in the anodic polarization curve under the deaerated condition. $\mathrm{X}$ ray analysis revealed the presence of hematite in the loose brownish oxide formed on specimens under the air-saturated condition. Consequently, passivation at higher potential under the air-saturated condition would be related to the presence of hematite which is formed by the transformation of magnetite into hematite.

Iron passive films in aqueous media are generally considered to consist of the inner layer of $\mathrm{Fe}_{3} \mathrm{O}_{4}$ and the outer layer of $\gamma-\mathrm{Fe}_{2} \mathrm{O}_{3}{ }^{(8)}$. However, it is not clear whether or not the presence of $\gamma-\mathrm{Fe}_{2} \mathrm{O}_{3}$ affects the high temperature passivity. Several workers $^{(9)}$ have reported the detection of $\gamma-\mathrm{Fe}_{2} \mathrm{O}_{3}$ in the oxide film produced in high temperature water. However, $\mathrm{Fe}_{3} \mathrm{O}_{4}$ and $\gamma-\mathrm{Fe}_{2} \mathrm{O}_{3}$ give a very similar pattern, so that it is very difficult to distinguish between these two structures $^{(10)}$. One possible difference between these two structures is characteristic diffraction lines from (210), (211) and (221) planes of $\gamma-\mathrm{Fe}_{2} \mathrm{O}_{3}$. The line intensity from these planes, however, was so weak that we were able to detect $\gamma-\mathrm{Fe}_{2} \mathrm{O}_{3}$, only at $250^{\circ} \mathrm{C}$ in the deaerated solution and at 200,250 and $280^{\circ} \mathrm{C}$ in the air-saturated solution. Further experiments should be made to clarify the relation between high temperature passivity and the structure of corrosion products.

From the standpoint of thermodynamics, potential$\mathrm{pH}$ diagrams for the iron-water system at high temperature have been reported by a few workers ${ }^{(11)(12)}$. In neutral solution as in the present work, the following possible reactions should be considered for interpreting the passive phenomena of mild steel.

(1) $3 \mathrm{Fe}+4 \mathrm{H}_{2} \mathrm{O}=\mathrm{Fe}_{3} \mathrm{O}_{4}+4 \mathrm{H}_{2} \quad \Delta G_{T}^{\circ}=-25110$ $+22.4 T-18.13 T \log p_{\mathrm{H}_{2} \mathrm{O}} \quad(\mathrm{cal} / \mathrm{mol})$

(2) $2 \mathrm{Fe}+3 \mathrm{H}_{2} \mathrm{O}=\mathrm{Fe}_{2} \mathrm{O}_{3}+3 \mathrm{H}_{2}$ $\Delta G_{T}^{\circ}=-17020+21.7 T-13.72 T \log p_{\mathrm{H}_{2} \mathrm{O}}$

(3) $2 \mathrm{Fe}_{3} \mathrm{O}_{4}+\mathrm{H}_{2} \mathrm{O}=3 \mathrm{Fe}_{2} \mathrm{O}_{3}+\mathrm{H}_{2}$ $\Delta G_{T}^{\circ}=-780+20.5 T-4.57 T \log p_{\mathrm{H}_{2} \mathrm{O}}$

(4) $\mathrm{H}_{2} \mathrm{O}=1 / 2 \mathrm{O}_{2}+\mathrm{H}_{2}$ $\Delta G_{T}^{\circ}=+58900-13.1 T-4.57 T \log p_{\mathrm{H}_{2} \mathrm{O}}$, where the temperature dependence of the standard free energy changes $\left(\Delta G_{T}^{\circ}\right)$ for the reactions are calculated by using thermodynamic data ${ }^{(13)}$. $T$ is the absolute temperature and $p_{\mathrm{H}_{2} \mathrm{O}}$ is water vapor pressure

Table 1 Standard free energy. $\left(\Delta G^{\circ}\right)$

\begin{tabular}{c|r|r|r|r|r}
\hline \multirow{2}{*}{ Reaction } & \multicolumn{5}{|c}{$\Delta G^{\circ}(\mathrm{kcal} / \mathrm{mol})$} \\
\cline { 2 - 6 } & $100^{\circ} \mathrm{C}$ & $150^{\circ} \mathrm{C}$ & $200^{\circ} \mathrm{C}$ & $250^{\circ} \mathrm{C}$ & $280^{\circ} \mathrm{C}$ \\
\hline$(1)$ & -16.76 & -20.75 & -24.60 & -28.19 & -31.40 \\
$(2)$ & -8.93 & -11.68 & -14.31 & -16.77 & -19.04 \\
$(3)$ & +6.87 & +6.52 & +6.40 & +6.25 & +5.90 \\
$(4)$ & +106.20 & +104.16 & +100.40 & +96.70 & +93.96 \\
\hline
\end{tabular}

Table 2 Standard electrode potentials $\left(E^{\circ}\right)$ and electrode potentials at $\mathrm{pH} 6$.

\begin{tabular}{c|c|c|c|c|c}
\hline & \multicolumn{3}{c}{ Volts (S.H.E.) } \\
\cline { 2 - 6 } & $100^{\circ} \mathrm{C}$ & $150^{\circ} \mathrm{C}$ & $200^{\circ} \mathrm{C}$ & $250^{\circ} \mathrm{C}$ & $280^{\circ} \mathrm{C}$ \\
\hline $\mathrm{pH}$ slope & $0.074 \mathrm{pH}$ & $0.084 \mathrm{pH}$ & $0.094 \mathrm{pH}$ & $0.104 \mathrm{pH}$ & $0.110 \mathrm{pH}$ \\
\hline $3 \mathrm{Fe}+4 \mathrm{H}_{2} \mathrm{O}=\mathrm{Fe}_{3} \mathrm{O}_{4}+8 \mathrm{H}^{+}+8 \mathrm{e}^{-}$ & $\begin{array}{c}-0.091 \\
(-0.535)\end{array}$ & $\begin{array}{c}-0.112 \\
(-0.616)\end{array}$ & $\begin{array}{c}-0.133 \\
(-0.697)\end{array}$ & $\begin{array}{c}-0.153 \\
(-0.807)\end{array}$ & $\begin{array}{c}-0.170 \\
(-0.830)\end{array}$ \\
\hline $2 \mathrm{Fe}+3 \mathrm{H}_{2} \mathrm{O}=\mathrm{Fe}_{2} \mathrm{O}_{3}+6 \mathrm{H}^{+}+6 \mathrm{e}^{-}$ & $\begin{array}{c}-0.065 \\
(-0.509)\end{array}$ & $\begin{array}{c}-0.084 \\
(-0.588)\end{array}$ & $\begin{array}{c}-0.103 \\
(-0.670)\end{array}$ & $\begin{array}{c}-0.121 \\
(-0.745)\end{array}$ & $\begin{array}{c}-0.138 \\
(-0.798)\end{array}$ \\
\hline $2 \mathrm{Fe}_{3} \mathrm{O}_{4}+\mathrm{H}_{2} \mathrm{O}=3 \mathrm{Fe}_{2} \mathrm{O}_{3}+2 \mathrm{H}^{+}+2 \mathrm{e}^{-}$ & $\begin{array}{c}+0.149 \\
(-0.295)\end{array}$ & $\begin{array}{c}+0.141 \\
(-0.363)\end{array}$ & $\begin{array}{c}+0.138 \\
(-0.426)\end{array}$ & $\begin{array}{c}+0.136 \\
(-0.488)\end{array}$ & $\begin{array}{c}+0.128 \\
(-0.532)\end{array}$ \\
\hline $\mathrm{H}_{2}=2 \mathrm{H}^{+}+2 \mathrm{e}^{-}\left(\mathrm{PH}_{2}=1\right)$ & $\begin{array}{c}0 \\
(-0.444)\end{array}$ & $\begin{array}{c}0 \\
(-0.504)\end{array}$ & $\begin{array}{c}0 \\
(-0.564)\end{array}$ & $\begin{array}{c}0 \\
(-0.624)\end{array}$ & $\begin{array}{c}0 \\
(-0.660)\end{array}$ \\
\hline $2 \mathrm{H}_{2} \mathrm{O}=\mathrm{O}_{2}+4 \mathrm{H}^{+}+4 \mathrm{e}^{-}\left(\mathrm{PO}_{2}=1\right)$ & $\begin{array}{c}+1.151 \\
(+0.707)\end{array}$ & $\begin{array}{c}+1.129 \\
(+0.625)\end{array}$ & $\begin{array}{c}+1.088 \\
(+0.524)\end{array}$ & $\begin{array}{c}+1.048 \\
(+0.424)\end{array}$ & +1.019 \\
$(+0.359)$
\end{tabular}

( ) Potential at $\mathrm{pH} 6$

(7) T. Fujii, T. Kobayashi, G. Ito and T. Shirouzu: The 37th meeting of Electrochemical Society, Japan, (1970).

(8) C. L. Foley, J. Kruger, and C. J. Bechtoldt: J. Electrochem. Soc. 114 (1967), 994.

(9) J. M. Moore, and R. L. Jones: J. Electrochem. Soc. 116
(1969), 1080.

(10) W. M. M. Huijbrgts: Mitteilung Der VGB., 51 (1971), 229.

(11) H. E. Townsend, Jr.: Corr. Sci., 10 (1970), 343.

(12) C. J. Mason and J. T. Harrison: CERL Report,(1966). 
Table 3 Peak potential values in potentiodynamic polarization curves.

\begin{tabular}{|c|c|c|c|c|}
\hline $\begin{array}{c}\text { Temperature } \\
\left({ }^{\circ} \mathrm{C}\right)\end{array}$ & $\begin{array}{l}\text { Corrosion } \\
\text { potential } \\
\text { V(S.C.E.) }\end{array}$ & $\begin{array}{l}\text { First } \\
\text { current } \\
\text { peak } \\
\text { V(S.C.E.) }\end{array}$ & $\begin{array}{l}\text { Second } \\
\text { current } \\
\text { peak } \\
\text { V(S.C.E.) }\end{array}$ & $\begin{array}{l}\text { Oxygen } \\
\text { evolution } \\
\text { V(S.C.E.) }\end{array}$ \\
\hline $\begin{array}{ll}200 \\
\text { De-aerated } \\
250 \\
280\end{array}$ & -0.70 & $\begin{array}{l}-0.28 \\
-0.25 \\
-0.25\end{array}$ & $\begin{array}{r}\overline{\overline{3}} \\
+0.38\end{array}$ & $\begin{array}{l}70 \\
50 \\
52\end{array}$ \\
\hline $\begin{array}{cc}\text { Air- } & 200 \\
\text { saturated } & 250 \\
280\end{array}$ & $\begin{array}{l}-0.25 \\
-0.27 \\
-0.25\end{array}$ & - & $\begin{array}{l}+0.30 \\
+0.30 \\
+0.25\end{array}$ & \\
\hline
\end{tabular}

at each test temperature. For convenience $p_{\mathrm{O}_{2}}=p_{\mathrm{H}_{2}}=$ 1 is assumed. In Table 1 , the standard free energies $\left(\Delta G^{\circ}\right)$ for these reactions are summarized at test temperatures. The standard electrode potentials for the corresponding electrochemical reactions are calculated in Table 2 by using the relation of $\Delta G^{\circ}=-n F E^{\circ}$, where $n$ is the number of electrons participating the reaction. $F$ is the Faraday constant and $E^{\circ}$ is the standard electrode potential on the hydrogen scale. The ion product $K_{w}$ of water increases up to $265^{\circ} \mathrm{C}$ and then decreases with increasing temperature, so that the neutral of water changes to $\mathrm{pH} \mathrm{5.6-5.9}$ in the temperature range of 200 to $300^{\circ} \mathrm{C}^{(14)}$. Thus the electrode potentials at $\mathrm{pH} 6$ are calculated at each test temperature in Table 2 by means of the Nernst equation, $E=E^{\circ}-R T / n F\left(\ln a_{\text {oxd }} / a_{\text {red }}\right)$ where $R$ is the gas constant and $a_{\mathrm{oxd}}, a_{\mathrm{red}}$ are the activities of oxydants and reductants.

From Table 2, the electrochemical reaction (1) is the most probable for the passivation at lower potential in deaerated solution. On the other hand, the passivation at higher potential under the air-saturated condition will be due to the reaction (3). Characteristic potential values in the measured anodic curves are shown in Table 3. A direct comparison of the measured values and the calculated equilibrium potentials will be difficult, since uncertain factors, such as thermal junction potential across a solution bridge and the temperature coefficient of standard electrode potentials, are involved in the present experiment. However, the measured potential difference between the first current peak (corresponding to the corrosion potential

(13) O. Kubaschewski, E. Evans, and C. B. Alcock: Metallurgical Thermodynamics (4th edition) (1967).

(14) J. R. Fisher and H. L. Barnes: J. Phy. Chem., 76 (1972), 90.

(15) E. C. Potter and G. M. W. Mann: 1st Int. Cong. Metal. Corr. London, (1961), p. 417.

(16) L. I. Freiman and Ya. M. Kolotyrkin: Zashch. Metal., 5 (1960), 139. under the air-saturated condition) and the oxygen evolution potential agreed fairly well with the difference between the calculated oxidation potential of $\mathrm{Fe}_{3} \mathrm{O}_{4}$ to $\mathrm{Fe}_{2} \mathrm{O}_{3}$ and the oxygen evolution potential. The first current peak, therefore, would be caused by the oxidation of magnetite to hematite.

The reaction at the second current peak which appeared at about $+0.30 \mathrm{~V}$, has not been established.

With regard to pitting, the anodic polarization curves under the deaerated condition, especially at 200 and $250^{\circ} \mathrm{C}$ showed a typical pitting behavior. The pitting potential was very close to the blip potential, which will correspond to the oxidation of $\mathrm{Fe}_{3} \mathrm{O}_{4}$ to $\mathrm{Fe}_{2} \mathrm{O}_{3}$. The pitting dissolution seemed to occur through pores in the oxide film. The specimen anodically polarized at $280^{\circ} \mathrm{C}$ showed no obvious pitting, but there were a number of pores which are usually observed in the boiler corrosion ${ }^{(15)}$. Although in the present work, $0.1 \mathrm{~N}$ sodium sulfate solution was chosen as one of neutral salts, sulfate anion may act as an aggressive anion ${ }^{(16)}$, so that further experiments with other kinds of anions are required to make clear the cause of the pitting.

\section{Conclusions}

From the present work, significant features of the high temperature passivity of mild steel are as follows:

(1) Very reproducible potential-time curves were recorded during heating. Although in deaerated solution, the change of the corrosion potential in the noble direction was not remarkable, the corrosion potential under the air-saturated condition changed markedly in the noble direction above $200^{\circ} \mathrm{C}$ and finally settled down at $-0.30 \mathrm{~V}$ at $280^{\circ} \mathrm{C}$.

(2) Under the deaerated condition, anodic polarization curves measured one hour after reaching the test temperature showed passive potential region above $200^{\circ} \mathrm{C}$. Pitting behavior was also observed at 200 and $250^{\circ} \mathrm{C}$.

(3) Under the air-saturated condition the passivation behavior was observed above $250^{\circ} \mathrm{C}$.

(4) The effect of potential increase and decrease for the polarization curve showed that the passivity at lower temperature was unstable.

(5) By X-ray and electron diffraction, passivity under the deaerated condition is attributed to the protective thin oxide film of magnetite and the presence of hematite will be related to the passivity under the air-saturated condition. 